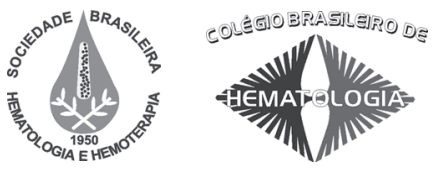

Review / Revisão

\title{
Infection in multiple myeloma
}

\section{Infecção em mieloma múltiplo}

Marcio L. M. Nucci

\begin{abstract}
Infections are significant causes of morbidity and the leading cause of death in patients with MM. Therapeutic strategies impact differently on the immune system, predisposing patients to various opportunistic infections. Myeloma and treatment-associated organ dysfunctions and co-morbidities also increase the risk of infection. Prospective epidemiologic studies of infections of myeloma patients from six centers from Brazil and one from Chile were performed. A total of 228 infectious episodes (median of 1; range: 1-13) were observed in 156 patients during one year. Median age was 57 years (range: 33-89), and 112 were men. Seventy-one percent of episodes occurred in Stage III (Durie-Salmon). Patients were divided into three phases according to the time of occurrence of infection related to the treatment of myeloma: phase $1=$ induction therapy, phase 2 =during HCT and phase $3=$ maintenance therapy or in relapse. Active myeloma and renal failure were risk factors in Phase 1; respiratory tract infections $(46 \%)$ and urinary tract infections (21\%) were the most frequent. In Phase 2, the risk factors were central venous catheters, neutropenia and mucositis; bacteremia (31\%) and fever of unknown origin (23\%) were the most frequent characteristics. Patients who were receiving corticosteroids were more probable to suffer infections in Phase 3 the most common being respiratory tract infections (44\%). Rates of infectious-related death were $14.5 \%$ in phase $1,5 \%$ in phase 2 and $14 \%$ in phase $3(P=N S)$. The introduction of novel life-prolonging therapies has transformed myeloma into a chronic disease. Resulting cumulative immunosuppression has increased the risk of infection and expanded the spectrum of potential pathogens in this patient population. Infections continue to represent a major challenge for clinicians caring for myeloma patients. Rev. Bras. Hematol. Hemoter. 2009;31(Supl. 2):32-34.
\end{abstract}

Key words: Multiple myeloma; epidemiologic study; infections.

\section{Introduction}

Infections are a significant cause of morbidity and the leading cause of death in patients with multiple myeloma. ${ }^{1-4}$ This susceptibility to infections is due, in part, to a reduction in the production of normal immunoglobulins, defects in the complement cascade, 5 and other factors related to MM. ${ }^{6}$

Over the last decade, substantial progress has occurred in the treatment of myeloma, with a favorable impact on survival. ${ }^{7}$ These advances include high-dose chemotherapy followed by autologous hematopoietic stem cell transplantation (HCT), allogeneic HCT, and the most recently introduced drugs, including bortezomib and the immunomodulatory agents, thalidomide and lenalidomide. ${ }^{3}$ These therapeutic strategies impact differently on the immune system, predisposing patients to various opportunistic infections.

In addition, myeloma and treatment-associated organ dysfunctions and co-morbidities have also increased the risk of infection. These include a) renal failure (cast nephropathy, hypercalcemia, deposition diseases, among others). ${ }^{8-10} \mathrm{~b}$ ) respiratory tract involvement caused by the collapse of

Associate Professor, Department of Internal Medicine, Universidade Federal do Rio de Janeiro - Rio de Janeiro-RJ.

Universidade Federal do Rio de Janeiro - Hospital Universitário Clementino Fraga Filho - Rio de Janeiro-RJ.

Correspondence: Marcio Luiz Moore Nucci

Rua Professor Rodolpho Paulo Rocco, 255 - $4^{\circ}$ andar, sala 4/12 - Ilha do Fundão

21.941-913 - Rio de Janeiro-RJ - Brasil

Tel.: (55 21) 2562-2463

E-mail:mnucci@hucff.ufrj.br 
thoracic vertebra and the opiate therapy (which may depress the central nervous system) prescribed to patients with painful fractures $;{ }^{11} \mathrm{c}$ ) severe alimentary mucosal damage (caused by chemotherapy, radiation therapy or graft-versus-host disease; ${ }^{12-14} \mathrm{~d}$ ) hyperglycemia induced by dexamethasone; ${ }^{15}$ e) transfusional iron overload; ${ }^{16,17}$ and $\mathrm{f}$ ) the multi-system involvement in myeloma-associated deposition diseases (amyloidosis and light chain deposit disease). ${ }^{18}$

Moreover, the prolonged survival resulting from novel therapies has transformed myeloma into a chronic condition, ${ }^{19}$ with multiple relapses and salvage therapies, all of which result in cumulative immunosuppression and higher risk of infection. Indeed, CD4+ T-cells, particularly naive and activated subsets, decline significantly with increasing cycles of chemotherapy, a decline strongly associated with opportunistic infections..$^{20}$

We have recently completed a prospective epidemiologic study of episodes of infection occurring in myeloma patients from six centers in Brazil and one in Chile. During a 1-year period we observed 228 infectious episodes in 156 patients (median one episode per patient; range: 1-13). Most of these patients were treated without the new drug, bortezomib. We divided the patients into three phases, according to the time of occurrence of infection related to the treatment of myeloma: Phase 1 included episodes occurring in induction therapy, Phase 2 included infections during HCT, and Phase 3 infectious episodes occurring during maintenance therapy or in relapse.

The median age was 57 years (range $33-89$ ), and 112 were men. The Durie-Salmon Stage was III in $71 \%$ of episodes. Patients with infectious episodes in Phase 1 were more likely to have active myeloma and renal failure as risk factors. Infections in phase 2 were more likely to be associated with a central venous catheter, neutropenia and mucositis, while patients with infections in phase 3 were more likely to have received corticosteroids. Respiratory tract (46\%) and urinary tract $(21 \%)$ were the most frequent sites of infections in Phase 1 , bacteremia $(31 \%)$ and fever of unknown origin $(23 \%)$ were the commonest features in Phase 2, and respiratory tract infections (44\%) were the most frequent in Phase 3. The rates of infectious-related death were $14.5 \%$ in Phase $1,5 \%$ in Phase 2 , and $14 \%$ in Phase 3 (not significant).

Infections continue to represent a major challenge for clinicians caring for myeloma patients. The introduction of novel life-prolonging therapies has transformed myeloma into a chronic disease. The resulting cumulative immunosuppression has increased the risk of infection and expanded the spectrum of potential pathogens in this patient population.

Managing infections begins with a risk-adapted selection of anti-myeloma therapy, taking into account tumorand host-related factors, with particular emphasis on disease and age-related organ dysfunction.

\section{Resumo}

Infecções são causas significantes de morbidade e podem levar à morte pacientes com MM. O impacto das estratégias terapêuticas sobre o sistema imunológico predispõe a várias infecções oportunistas e disfunções orgânicas que podem aumentar o risco de infecções. Estudo epidemiológico de infecções em pacientes com MM foi feito em seis centros brasileiros e um chileno. Foram observados 228 episódios de infecção (mediana 1; 1-13) em 156 pacientes durante um ano. A idade mediana foi 57 anos (33-89) e foram 112 pacientes masculinos. Estágio III de Durie-Salmon em $71 \%$ dos episódios. Os pacientes foram divididos em três fases de acordo com o tempo de ocorrência de infecção relacionado ao tratamento do mieloma: fase 1 - terapia de indução; fase 2 durante transplante e fase 3 - terapia de manutenção ou recidiva. Fase 1 que ocorreu durante doença ativa e falência renal como fatores de risco; infecção do trato respiratório (46\%) e infecção urinária (21\%) ,foram os mais frequentes. Fase 2 ocorreu provavelmente devido a cateter central, neutropenia e mucosite; bacteremia (31\%) e FOI (23\%) foram os mais frequentes. Fase 3 ocorreu mais frequentemente em pacientes recebendo cortecosteroides; infecção do trato respiratório (44\%) foi o mais frequente. As taxas de morte relacionado à infecção foram 14,5 na fase 1, 5\% na fase 2 e 14\% na fase 3 (NS). A introdução de terapêuticas que prolongam a vida tem transformado o MM em doença crônica. A imunossupressão acumulada tem aumentado o risco de infecção e elevado a amplitude de potencial de patógenos. Infecções continuam representando o maior desafio para os clínicos que cuidam de pacientes com MM. Rev. Bras. Hematol. Hemoter. 2009;31(Supl. 2):32-34.

Palavras-chave: Mieloma múltiplo; estudo epidemiológico, infecções.

\section{References}

1. Augustson BM, Begum G, Dunn JA, Barth NJ, Davies F, Morgan G, et al. Early mortality after diagnosis of multiple myeloma: analysis of patients entered onto the United kingdom Medical Research Council trials between 1980 and 2002--Medical Research Council Adult Leukaemia Working Party. J Clin Oncol. 2005;23(36):9219-26.

2. Kapadia SB. Multiple myeloma: a clinicopathologic study of 62 consecutively autopsied cases. Medicine (Baltimore). 1980;59 (5):380-92.

3. Kyle RA. Multiple myeloma: review of 869 cases. Mayo Clin Proc. 1975;50(1):29-40.

4. Oshima K, Kanda Y, Nannya Y, Kaneko M, Hamaki T, Suguro M, et al. Clinical and pathologic findings in 52 consecutively autopsied cases with multiple myeloma. Am J Hematol. 2001;67(1):1-5.

5. Kraut EH, Sagone AL Jr. Alternative pathway of complement in multiple myeloma. Am J Hematol. 1981;11(4):335-45.

6. Prabhala RH, Neri P, Bae JE, Tassone P, Shammas MA, Allam CK, et al. Dysfunctional T regulatory cells in multiple myeloma. Blood. 2006;107(1):301-4

7. Rajkumar SV, Kyle RA. Multiple myeloma: diagnosis and treatment. Mayo Clin Proc. 2005;80(10):1371-82.

8. Kuroki Y, Tsuchida K, Go I, Aoyama M, Naganuma T, Takemoto Y, et al. A study of innate immunity in patients with end-stage renal 
disease: special reference to toll-like receptor-2 and -4 expression in peripheral blood monocytes of hemodialysis patients. Int $\mathrm{J}$ Mol Med. 2007;19(5):783-90.

9. Sung JM, Ko WC, Huang JJ. Candidaemia in patients with dialysisdependent acute renal failure: aetiology, predisposing and prognostic factors. Nephrol Dial Transplant. 2001;16(12):2348-56.

10. Abbott KC, Hypolite I, Tveit DJ, Hshieh P, Cruess D, Agodoa LY. Hospitalizations for fungal infections after initiation of chronic dialysis in the United States. Nephron. 2001;89(4):426-32.

11. Abbas Z, Jafri W, Rasool S, Abid S, Hameed I. Mucormycosis in patients with complicated cirrhosis. Singapore Med J. 2007;48 (1):69-73.

12. Sonis ST, Oster G, Fuchs H, Bellm L, Bradford WZ, Edelsberg J, et al. Oral mucositis and the clinical and economic outcomes of hematopoietic stem-cell transplantation. J Clin Oncol. 2001;19(8): 2201-5.

13. Jham BC, França EC, Oliveira RR, Santos VR, Kowalski LP, da Silva Freire AR. Candida oral colonization and infection in Brazilian patients undergoing head and neck radiotherapy: a pilot study. Oral Surg Oral Med Oral Pathol Oral Radiol Endod. 2007;103(3):355-8.

14. McDonald GB. Oral beclomethasone dipropionate: a topically active corticosteroid for the treatment of gastrointestinal graft-versushost disease following allogeneic hematopoietic cell transplantation. Expert Opin Investig Drugs. 2007;16(10):1709-24.

15. Khardori R, Adamski A, Khardori N. Infection, immunity, and hormones/endocrine interactions. Infect Dis Clin North Am. 2007;21(3):601-15, vii.

16. Miceli MH, Dong L, Grazziutti ML, Fassas A, Thertulien R, Van Rhee $\mathrm{F}$, et al. Iron overload is a major risk factor for severe infection after autologous stem cell transplantation: a study of 367 myeloma patients. Bone Marrow Transplant. 2006;37(9):857-64.

17. Pietrangelo A. Iron chelation beyond transfusion iron overload. Am J Hematol. 2007;82(12 Suppl):1142-6.

18. Lachmann HJ, Goodman HJ, Gilbertson JA, Gallimore JR, Sabin CA, Gillmore JD, et al. Natural history and outcome in systemic AA amyloidosis. N Engl J Med. 2007;356(23):2361-71.

19. Ghobrial IM, Anderson KC. The road to cure in multiple myeloma. Blood. 2008; 111:2503.

20. Schütt P, Brandhorst D, Stellberg W, Poser M, Ebeling P, Müller S, et al. Immune parameters in multiple myeloma patients: influence of treatment and correlation with opportunistic infections. Leuk Lymphoma. 2006;47(8):1570-82.

O tema apresentado foi proposto pela Organização do $8^{\circ}$ Simpósio da Associação Ítalo-Brasileira de Hematologia, realizado durante o XIII Congresso de Transplante de Medula Óssea.

Publicado após concordância do editor.

Conflito de interesse: sem conflito de interesse

Recebido: 25/06/2009

Aceito: 08/07/2009 